\title{
THE EFFECTIVENESS OF SILENT WAYIN IMPROVING STUDENT LINGUISTIC PERFORMANCE IN INTENSIVE ENGLISH COURSE (IEC) CLASS
}

\author{
PATHUL INDRIANA \\ STMIK MATARAM ${ }^{1}$ \\ bufhatul@gmail.com
}

\begin{abstract}
Abstrak -this classroom research answers the two questions in the research problems. Firstly, Silent Way Method is so effective in improving student linguistic performance in Intensive English Course at Year 2 students in the Department of English Education Program at the Faculty of Teachers Training and Education as it explores students speaking skill to emerge and those who are shy feel confident to speak English even a bit. Secondly, it is so clear that Silent Way Method gives evidence to us that it can significantly improved student linguistic performance in Intensive English Course at Year 2 students in the Department of English Education Program at the Faculty of Teachers Training and Education by looking at the evidence as follows: 1)Teacher can provide oral fluency practice using presentation and group work model, 2) Teacher succeeds very well in achieving direct error correction and the discourse is allowed to proceed with minimum interruption, 3) In giving content feedback, teacher suceeds to create an atmosphere which is conducive to learning and is likely to promote learner involvement, 4) By constantly checking for confirmation, it creates considerable evidence that teachers who constantly seek clarification, check for confirmation and who do not always accept the first contribution a student offers are more likely to maximize linguistic performace potential than those who do not constantly, 5) Teacher succeeds in engaging students and in promoting longer verbal communication. His verbal behaviour allows students to play a full and active role in classroom, producing more complete, more natural responses, 6) Teacher only intervenes when necessary, giving language support, correcting errors or adding a personal comment, 7) As far as the learner contributions are concerned, it is evident from this extract that learners and teacher are actively engaged in constructing a piece of discourse which resembles a conversation. Silent Way Method indeed has a number of positive effects, from an excited, questioning approach to teaching to improved classroom interaction and involvement with the students. By controlled use of language and by matching pedagogic and linguistic goals, teacher facilitates and promotes reformulation and clarification, leading to greater involvement and precision of language on the part of the learners.
\end{abstract}

Key Words : Effectifeness, Sylent way, linguistics performance.

\section{INTRODUCTION}

\subsection{Background of Study}

The study starts from the assumption that classroom communication in Intensive English Course class at Year 3 students of the Department of English Education Program at FKIP UGR is more teacher-centered than studentcentered. Students linguistic performance (or sometimes verbal behaviour or speaking skill) in classroom today is limited in time length by the teachers. Students are to a large extent restricted in their choice of language. Instead, teachers increase their talking time and dominantly control the student linguistic performance.

Several backgrounds the writer finds interesting in this study are as follows:
1. Teachers largely control the topic of discussion;

2. Teachers often control both content and procedure;

3. Teachers usually control who may participate and when;

4. Students take their cues (signals) to speak from teachers;

5. Teachers talk most of the time;

6. Teachers modify their talk to learners (structurally and grammatically);

7. Learners rarely modify their talk to teachers;

8. Teachers ask questions (to which they know the answers) most of the time 


\subsection{Research Questions}

Based on the background of the study above, the writer proposes two research questions as follows:

1. How effective is Silent Way Method in improving student linguistic performance in Intensive English Course (IEC) class at Year 3 Students in the Department of English Education Program at FKIP Gunung Rinjani University (UGR)?

2. What is the evidence found by using Silent Way Method in improving in learner linguistic performance in Intensive English Course (IEC) class at Year 3 Students in the Department of English Education Program at FKIP Gunung Rinjani University (UGR)?

\subsection{Purpose of Study}

The purposes of this study are:

1. To find out how effective Silent Way Method is in improving student linguistic performance in Intensive English Course (IEC) class at Year 3 Students in the Department of English Education Program at FKIP Gunung Rinjani University (UGR)?

2. To find out evidence found by using Silent Way Method in improving learner linguistic performance in Intensive English Course (IEC) class at Year 3 Students in the Department of English Education Program at FKIP Gunung Rinjani University (UGR)?

\subsection{Purpose of Study}

The purposes of this study are:

1. To find out how effective Silent Way Method in improving student linguistic performance in Intensive English Course (IEC) class at Year 3 Students in the Department of English Education Program at FKIP Gunung Rinjani University (UGR)?
2. To find out evidence found by using Silent Way Method in improving in learner linguistic performance in Intensive English Course (IEC) class at Year 3 Students in the Department of English Education Program at FKIP Gunung Rinjani University (UGR)?

\subsection{Scope of Study}

The scope of this study is limited to:

1. Investigate the effectiveness of Silent Way Method in improving student linguistic performance in Intensive English Course (IEC) class at Year 3 Students in the Department of English Education Program at FKIP Gunung Rinjani University (UGR)?

2. Investigate the evidence found by using Silent Way Method in improving in learner linguistic performance in Intensive English Course (IEC) class at Year 3 Students in the Department of English Education Program at FKIP Gunung Rinjani University (UGR)?

\subsection{Significance of Study}

expected to:

The significance of this study is

1. give positive input for the development of Intensive English Course (IEC) in the Department of English Education Program at the Faculty of Teachers Training and Education;

2. develop better way in techniques and methods of teaching Intensive English Course (IEC) in the Department of English Education Program at the Faculty of Teachers Training and Education;

3. improve student linguistic performance through their choice of language;

4. construct learner participation in classroom communication in which 
teachers can improve their teacher talk to facilitate and optimize learner contributions.

5. aid both the students and teacher through a collegial process to develop good understandings of what happens in the language classroom.

\subsection{Definitions of Key Terms}

In order to avoid misunderstanding, the writer needs to define some important terms presented in this paper.

\section{Effectiveness}

a. Effectiveness is the extent to which an activity fulfils its intended purpose or function (Harvey. 2004-12).

b. Effectiveness is a measure of the match between stated goals and their achievement. It is always possible to achieve 'easy', lowstandard goals. In other words, quality in higher education cannot only be a question of achievements 'outputs' but must also involve judgements about the goals (part of 'inputs') (Fraser. 1994. p. 104).

c. Effectiveness in education is an output of specific review/analyses that measure (the quality of) the achievement of a specific educational goal or the degree to which a higher education institution can be expected to achieve specific requirements. As a primary measure of success of a programme or of a higher education institution, clear indicators, meaningful information, and evidence best reflecting institutional effectiveness with respect to student learning and academic achievement have to be

\author{
gathered through various \\ procedures (inspection, \\ observation, site visits, etc.) \\ (Vlãsceanu et al. 2004. p. 37).
}

\section{Silent Way Method}

Silent Way Method is one of the ELT methods which restricted the amount of TTT in teaching/learning process (Michalkova. 2011).

\section{Linguistic Performance}

a. Linguistic performance is the behavior of producing actual, authentic utterances (Williamson. 2011).

b. Linguistic performance (linguistics) is a speaker's actual use of language in real situations; what the speaker actually says, including grammatical errors and other non-linguistic features such as hesitations and other disfluencies (contrasted with linguistic competence) (The Free Dictionary.com. 2012).

\section{Linguistic competence}

Linguistic competence is an abstract, internalized ability that allows us to reject certain utterances as ungrammatical and the ability to interpret grammatical utterances that we have never heard before (The Free Dictionary.com. 2012).

\section{Teacher talking time (TTT)}

Teacher Talking Time (TTT) is the time that teachers spend talking in class, rather than learners. It can be compared with, student-talking time. One key element of many modern approaches is to reduce the amount of TTT as much as possible, to allow learners opportunities to speak, and learn from speaking . 


\section{Student Talking Time (STT)} Student Talking Time (STT) is the time that students spend talking in class, rather than teachers.

\section{LITERATURE REVIEW}

\subsection{Intensive Course (IC) Program}

As an important part of the curriculum being developed for the training of high school teachers of English, a successful implementation of IC program is crucial. This is an academic program that is organized along the following major points:

(1) IC is a two-semester program of 8 credits conducted in the first semester and third semester; and required of all new students majoring in the teaching of English.

(2) It is a course conducted intensively with an average number of 4 SKS or 64 class-hours throughout the first semester.

(3) The main objective of the course is to establish fluency in English on the part of the students. At the end of the IC program the students are expected to have mastered the basic English language skills, especially listening, reading, speaking, as well as basic grammar and vocabulary.

(4) The materials for teaching are specially selected, organized, developed, and used in an integrated manner for the mastery of basic English language skills as a whole, not necessarily limited to each one of them.

(5) Students' progress and achievement in the course is to be evaluated periodically so that corrective and remedial steps can be done in due time.

Aspects of instructional materials that need to be discussed include the types of materials and how the materials were organized. The instructional materials consisted of two volumes of student's handbooks, two volumes of student workbooks, one teacher's guide (Kadarisman \& Murdibjono, 2000a; 2000b; 2000c), and 25 cassettes of recorded materials along with the tapescripts (Intensive Course Program, 2000a). These materials were used in all the teachers' colleges. In addition, for independent study the students were given listening and reading materials that were prepared by each teachers' college. Therefore, the types of materials for independent study varied from one teachers' college to another. For example, the IC students of UNESA were given Listen Carefully for listening activities (Retnaningdyah, et al, 2001) and reading passages from Collins English library and Growing in English Language Skills (Finocchiaro \& Lavanda, 1987) for reading activities.

The instructional materials in the student' handbooks were graded and divided into lessons and units. There were 30 lessons and each lesson consisted of four units (A few lessons, however, had 3 units). In each unit, the materials were presented in a typical form of organization with the following sections:

1. Conversation

2. Vocabulary focus

3. Explanation

4. Let's practice

5. Pronunciation

6. Communicative activities

7. Listening

In the conversation section, new words and expressions mostly relevant with the topic of a particular unit are introduced in a conversational context. The vocabulary focus section lists important words and expressions used in the unit. The explanation section concerns grammatical structures. Let's practice contains exercises on grammatical items explained in the previous part. The pronunciation section contains a brief explanation on articulatory phonetics, pronunciation model, and pronunciation practice. The communicative activities section contains various activities, ranging from simple conversation involving peers to role-plays and games. The listening section contains exercises based on the explanation and let's practice sessions. In the 
listening exercises, the students were assigned to respond to the instructions from the tape recorder. In this section, the students were occasionally given songs to sing together or jazz chants to practice.

The student's workbooks provide enrichment materials, including writing for spelling accuracy and for grammar reinforcement. The workbooks also give prompts and models for some of the listening activities so that the students could be helped in following the sequence of presentation in the listening section. The tapescripts are the written version of the recorded materials. The teacher's guide contains information on how the IC program should be implemented and keys to some quizzes and riddles in the student's handbooks (Cahyono. 2002: 23 - 35).

\subsection{Silent Way Method}

The Silent Way is a language teaching method created by Caleb Gattegno that makes extensive use of silence as a teaching technique. It is not usually considered a mainstream method in language education. It was first introduced in Gattegno's book Teaching Foreign Languages in Schools: The Silent Way in 1963. Gattegno was skeptical of the mainstream language education of the time, and conceived of the method as a special case of his general theories of education.

The method emphasises the autonomy of the learner; the teacher's role is to monitor the students' efforts, and the students are encouraged to have an active role in learning the language. Pronunciation is seen as fundamental; beginning students start their study with pronunciation, and much time is spent practising it each lesson. The Silent Way uses a structural syllabus, and structures are constantly reviewed and recycled. The choice of vocabulary is important, with functional and versatile words seen as the best. Translation and rote repetition are avoided and the language is usually practiced in meaningful contexts. Evaluation is carried out by observation, and the teacher may never set a formal test.

The teacher uses silence for multiple purposes in the Silent Way. It is used to focus students' attention, to elicit student responses, and to encourage them to correct their own errors.
Even though teachers are often silent, they are still active; they will commonly use techniques such as mouthing words and using hand gestures to help the students with their pronunciation. Teachers will also encourage students to help their peers.

Silent Way teachers use some specialized teaching materials. One of the hallmarks of the method is the use of Cuisenaire rods, which can be used for anything from introducing simple commands to representing abstract objects such as clocks and floor plans. The method also makes use of color association to help teach pronunciation; there is a sound-color chart which is used to teach the language sounds, colored word charts which are used to teach sentences, and colored Fidel charts which are used to teach spelling.

\subsection{Common Problems in Speaking for Indonesian Students}

Keating (2012) and Najah (2010) summarized common problems in speaking for Indonesian students as follows:

\section{Teacher-centered}

First, the Indonesian education system (or at least the system which today's teenage and adult language learners passed through) tends to produce students with preconceived notions of ways to be taught. Often this means passive learners expecting to absorb information from the teacher, who is the center of a class, an authority figure, and someone who must not be questioned. Language learning is most effective in an environment where active students feel free to participate, get involved and ask questions; an environment where students know that making mistakes is the best way to learn, and where making a mistake does not result in loss of face.

2. Based on teaching more theoritical knowledge

It seems that the content of a great deal of Indonesian schools' English language curriculum is based on the teaching of theoretical knowledge as opposed to developing functional, 
communicative language skills. Often this means that the Indonesian ESL student is able to produce complex grammatic forms, but has little awareness of the actual meaning of the language they are producing. Upon prompting, A student would be able to write a correct sentence using, for instance, the present perfect continuous tense, but when questioned as to the real usage and the meaning of the grammatical form, many high school graduates are stumped.

3. L1 (first language) interference

There are the problems resulting from L1 (first language) interference. In terms of pronunciation, many Indonesians have trouble pronouncing consonant clusters (3 or more consonants together is a word), as these clusters do not occur in Bahasa Indonesia. The rolling of the letter ' $r$ ' is another common issue, but not one which causes any kind of strain for the listener. In general, pronunciation is not a huge problem for Indonesians, especially when compared to learners from Asian countries with tonal languages such as China and Vietnam.

\section{No tenses in Bahasa Indonesia}

Bahasa Indonesia does not have tenses as such, and a simplified method of talking about different points in time is often attempted in English (for example, 'yesterday I go'). The concept of tenses, especially the more complex perfect tenses, is often difficult to grasp for Indonesian students. Similarly, Indonesian English students often have trouble creating sentences with correct word order, again caused by the word order patterns in their first language (for example, 'the tree big').

\section{Spelling}

Finally, most Indonesian words are spelled phonetically, creating problems with learning the inconsistent, almost random way in which many English words are spelled.

\subsection{Problem with the Excessive Teacher Talking Time}

Too much teacher talking time can be a problem. Many training courses insisted that teacher talking time (TTT) was counterproductive and that teachers should reduce TTT for a number of reasons:

1. Excessive TTT limits the amount of STT (student talking time). If the teacher talks for half the time in a 60 minute lesson with 15 students, each student gets only 2 minutes to speak.

2. A large amount of TTT results in long stretches of time in teacher-to-class (T/class) mode and a monotonous pace. Student under-involvement inevitably leads to loss of concentration, boredom and reduced learning.

3. TTT often means that the teacher is giving the students information that they could be finding out for themselves, such as grammar rules, the meanings of vocabulary items and corrections. Teacher explanations alone are often tedious, full of terminology and difficult to follow. There may be no indication of whether the students have understood.

4. If the teacher takes the dominant role in classroom discourse in terms of initiating the topic, allocating turns and evaluating comments, the student's role is only that of respondent. Opportunities for developing the speaking skill are therefore severely limited.

5. If the teacher is constantly dominant and controlling, the learners take no responsibility for their own learning but learn what the teacher decides and when. Student autonomy is thus limited.

\section{RESEARCH METHODOLOGY}




\subsection{Focus of Inquiry}

This research focuses on: investigating the effectiveness of Silent Way Method in improving student linguistic performance in Intensive English Course class at Semester 3 Students in the Department of English Education Program at FKIP Gunung Rinjani University; and (2) investigating evidence found by using Silent Way Method in improving learner linguistic performance in Intensive English Course class at Semester 3 Students in the Department of English Education Program at FKIP Gunung Rinjani University.

\subsection{Setting and Participants \\ 3.2.1 Setting}

This inquiry will be conducted at the English Education Program Faculty of Teachers Training and Education University of Gunung Rinjani, Anjani East Lombok. It will take place at Semester 3 students academic year 2017/2018. The writer uses group working (GW) in which students will do presentation with the selected topics.

\subsubsection{Participants}

The participants of this research are all Semester 3 students in the Department of English Education Program at FKIP Gunung Rinjani University Anjani East Lombok. The participants consist of one class of 30 students, 8 female students and 22 male students.

\subsection{Research Methodology}

Teacher uses a presentation model through group working to investigate the effectiveness of Silent Way Method in improving students linguistic performance in Intensive English Course class. This presentation model and group working aim at training and improving students linguistic performance as well as empowering students self-confidence to speak English in front of their peer students in classroom. This is so true since the paticipants are teacher-to-be students in the future. The worst nightmare a teacher face in teaching is to speak in public. Whenever this problem can be overcome, the rest will follow. The first presentation would hardly meet $100 \%$ goal, yet it is worth to try. Teachers must always remind their students these quotations: (1) 'practice makes perfect', (2) learning is a trial and error, and 'the biggest teachers make the biggest mistakes' (Chris Regan).

The data in this reasearch will be analyzed by using Qualitative method.

\subsection{Classroom Research \\ 3.3.1 Group Working}

On the first meeting, writer will divide the whole 30 students into 10 groups of 3 (see Table 2 for list of group members and topics selected).

\subsubsection{Selecting a Topic}

There are 10 topics that will be presented in the group presentation. Each group will choose one topic they want to present. Male students will choose $40 \%$ of the total topics; female students will choose $40 \%$ of the total topics; and the teacher will choose $20 \%$ of the total topics. The topics must be interesting and fun since they are chosen by the students themselves. This will make them feel free and fearless since it might be that they have already prepared and known about the material they are going to present.

\subsubsection{Classroom Role Play}

Teacher explains the presentation role play to the students as clear as possible so that all of them understand the role play in classroom.

1. Group 1 though 10 will present the materials in turn.

2. All of the group members must present the material in turn.

3. The presentation is divided into 2 sessions: Session 1 for presentation and Session 2 for Question and Answer (QNA).

4. Each group will present the material in 45 minutes. So, there will be three groups to present per meeting.

5. Teacher will give comment and feedback at the end every presentation, feedback can be given during presentation if needed but limited to very important cases.

6. Each group must summarize a handout about the topic.

7. The hand-out will be shared 1 per group and 1 for teacher.

8. Each group must write a glossary at the end of the text. This is hoped to facilitate and familiarize students important and difficult words.

\subsection{Data Collection}

Teacher would like to colect data by means of recording the presentation, however, 
due to technological constraint and time limitation that writer had to work with the data as soon as possible, the plan for this moment could not run as intended. The writer realize that without tape recording the evidence, this research is not valid and reliable. If only, the writer had plenty of time, the data collection would run well. I really beg your pardon for this inconvenient, Sir.

Despite the invalid data, the writer made some important notes for the presentation chronologically, although it is in general, not in details.

\subsection{Result of the Study}

Based on data collected during the presentation, the writer analyzes the data by using qualitative method.

\subsubsection{Presentation Chronology}

Writer noted several important procedures in classroom during the presentation.

\section{(1) Students (S)}

a. S came on time.

b. Each group presenting the material were ready with their hand-outs material.

c. During Session 1: the group presenting the material produced language in real time conversation during presentation

d. S audience was very enthusiastic watching and listening to the group presenting the material.

e. During Session question and answer, audience was very enthusiastic and confident asking and commenting the group for more explanation and anwers. At this stage, audience asked more questions than expexted, more than eight questions including comments for Group one. The class was so alive, fun but controlled.

(2) Teacher (T)

a. $T$ monitored Ss working in groups completing a discussion.

b. During the presentation, $\mathrm{T}$ did fairly little talking, limiting himself to clarification of the incorrect pronunciation and offering language when requested.

c. During session question and answer, $T$ moderated several difficult vocabularies and incorrect pronunciation in which the Ss did not know. d. T gave answers to difficult questions that $S$ really wanted to know the answers based on objective or probably subjective opinion and arguments.

e. $T$ led an inductive grammar presentation and talked more before the class dismissed. T explained, illustrated and checked Ss understanding.

f. During presentation, $T$ reduced talking time and let the natural communication flow among Ss. Ss were very enthusiastic and passionate until the last minute of presentation, both male and female Ss were active and felt free to speak their mind (opinion).

g. T gave Ss more talking time, almost $90 \%$ of the whole length of presentation.

h. During question and answer session, $\mathrm{T}$ explored Ss personal opinon and thought to the topics. At this stage, T allowe Ss to use a mix sentence in English and Bahasa Indonesia. This is hoped to give chance for shy students to speak their mind.

\subsection{Grammatical Errors}

Teacher found some grammatical errors such as the tenses, the sentence structure, phrase order, pronunciation error, wrong words, occured during the presentation, but this is not the biggest concern for semester 3 students since the most important purpose of this method is to build students confidence to speak English, the more confident they are, the more happy and serious they will learn English.

\section{CONLUSSION}

In conclusion, this classroom research answers the two questions in the research problems. Firstly, Silent Way Method is so effective in improving student linguistic performance in Intensive English Course at Year 2 students in the Department of English Education Program at the Faculty of Teachers Training and Education as it explores students speaking skill to emerge and those who are shy feel confident to speak English even a bit.

Secondly, it is so clear that Silent Way Method gives evidence to us that it can significantly improved student linguistic performance in Intensive English Course at Year 
2 students in the Department of English Education Program at the Faculty of Teachers Training and Education by looking at the evidence as follows:

1. Teacher can provide oral fluency practice using presentation and group work model.

2. Teacher succeeds very well in achieving direct error correction and the discourse is allowed to proceed with minimum interruption.

3. In giving content feedback, teacher suceeds to create an atmosphere which is conducive to learning and is likely to promote learner involvement.

4. By constantly checking for confirmation, it creates considerable evidence that teachers who constantly seek clarification, check for confirmation and who do not always accept the first contribution a student offers are more likely to maximize linguistic performace potential than those who do not constantly.

5. Teacher succeeds in engaging students and in promoting longer verbal communication. His verbal behaviour allows students to play a full and active role in classroom, producing more complete, more natural responses.

6. Teacher only intervenes when necessary, giving language support, correcting errors or adding a personal comment.

7. As far as the learner contributions are concerned, it is evident from this extract that learners and teacher are actively engaged in constructing a piece of discourse which resembles a conversation.

Silent Way Method indeed has a number of positive effects, from an excited, questioning approach to teaching to improved classroom interaction and involvement with the students. By controlled use of language and by matching pedagogic and linguistic goals, teacher facilitates and promotes reformulation and clarification, leading to greater involvement and precision of language on the part of the learners.

\section{REFERENCES}

Cahyono, B.Y. How English Intensive Course Program Affects the English Proficiency of Students of Teachers' Colleges in Indonesia. Volume 4, Number 1, June 2002: 23 - 35. Universitas Kristen Petra. http://puslit.petra.ac.id/journals/letters/.

Downloaded: 18/11/2012. 5.35 PM.
Fraser. 1994. p. 104 in http://www.qualityresearch international.com

/glossary/effectiveness.htm. Downloaded: 18/11/2012. 3.25 PM.

Harvey, L. 2004-12. Analytic Quality Glossary http://www.qualityresearchinternational.com/glossary/effectiveness.htm. Downloaded: 18/11/2012. 3.15 PM.

Vlãsceanu et al., 2004, p. 37. UNESCO in http://www.qualityresearch international.com/glossary/effectiveness.ht m. Downloaded: 18/11/ 2012. 3.20 PM.

Walsh, S. 2002. Construction or obstruction: teacher talk and learner involvement in the EFL classroom. Hodder Arnold Journals. Vol 6, no 1, p. 3-23.

Williamson, G. Linguistic performance and Linguistic competence. http://www.speechtherapy-information-and-resources. com/linguis-tic-performance-and-linguisticcompet ence.html. Posted: Wednesday, 15 June 2011. 05:35. Downloaded: 18/11/2012. 3.05 PM.

http://universityofibnkhaldunbogorindonesia.blogs pot.com/2010/01/reas0n-why-students-arespeechless-in.html.

http://vladimiramichalkova.edublogs.org/2011/02/ 04/eltchat-teacher-talk-ing-time-vsstudents-talking-time/. Effective ways to minimize TTT (Teacher Talking Time) and maximize STT (Student Talking Time). Posted: 2 Feb 2011. Downloaded: 18 Nov 2012. 3.30 PM.

http://www.thefreedictionary.com/linguistic+compe tence. Downloaded: 18 Nov 2012. 3.05 PM.

Najah, I.F. The Reason Why Students are Speechless in Speaking Class. http://universityofibnkhaldunbogorindonesia .blogspot.com/2010/01/ reason-whystudents-are-speechless-in.html. Posted: 21/1/2010. Downloaded: 18/11/2012. 5.40 PM. 